\author{
E-ISSN: 2469-6501 \\ VOL: 7, ISSUE: 12 \\ December/2021 \\ DOI: http://dx.doi.org/10.33642/ijbass.v7n12p3 \\ (c) (i) \\ https://creativecommons.org/licenses/by/4.0/
}

\title{
Influence of Celebrity Endorsement On the Purchase of Slim Tea by Female Undergraduate Students in Selected Southeast Nigerian Universities
}

\author{
ANYAKOHA, B.U. \\ Department of Mass Communication \\ University of Nigeria \\ Email: belinda.anyakoha@unn.edu.ng \\ Nigeria \\ Odenigbo, C.I. \\ Department of Mass Communication \\ University of Nigeria \\ Email: cynthiaodenigbo1@gmail.com \\ Nigeria \\ Akata, U.C.M \\ Department of Mass Communication \\ University of Nigeria \\ Email: ukamaka.akata@unn.edu.ng \\ Nigeria
}

\begin{abstract}
This study explored the influence exerted by celebrity endorsement on the purchase of slim tea products by female undergraduate students in universities in southeast Nigeria. Specifically, the study aimed to determine the relationship between the brand image of slime tea and celebrity endorsement, identify how celebrity choice influences the brand image of a product, and also examine how female undergraduate students' choice of brand product is driven by celebrity influence. The population of this study consisted of female undergraduate students in the University of Nigeria Nsukka, Michael Okpara University of Agriculture Umudike, Madonna University Okija, and Ebonyi State University Abakiliki. A multistage sampling technique was used to arrive at a required sample size of 383. I did an oversampling and a total of 400 copies of the questionnaire were distributed and 392 copies of this questionnaire were filled and returned, making for a return rate of 98\%. Findings from this study showed that respondents believe that celebrity endorsement can influence their brand choice. And that the choice of celebrity used matters a lot. If an organization fails to provide a positive and strong brand image, it may directly or indirectly affect consumers' decision-making; as consumers may shift to competitors that offer a better experience. From the findings of this study, it is recommended that advertisers should make use of the right celebrities to enhance the brand image of their products and also consider celebrities whose profession and lifestyle are in sync with the products and services that they are endorsing.
\end{abstract}

\section{Keywords: Celebrity endorsement, slim tea, brand image, celebrity influence, advertising, marketing.}

\section{Introduction}

A celebrity is a famous person, one who is popular and powerful and that is very much appreciated. One who is very much talked about by most individuals in a society; they may be an artist, an actor, or a famous scholar. Celebrities are individuals who appreciate the open acknowledgment and who often have distinctive qualities such as attractiveness and trustworthiness (Silvera and Austad, 2004).

A celebrity endorser is "any person who appreciates open recognition and who uses this recognition on behalf of a consumer good by showing up with it in an advertisement" (McCracken 1989). According to Friedman and Friedman (1979), in the promotion of products high in psychological and/or social risk, the use of celebrity endorsers would lead to greater believability, a more favorable evaluation of the product and advertisement, and a significantly more positive purchase intention. Celebrity endorsements are now common in the advertising world as an advertising strategy to cajole customers into purchasing their goods and services. Celebrity endorsement influences the brand image of a product as people automatically assume the product must be good and of a high standard. According to Wimmer and Domonic (2014), "when you get a celebrity to endorse your company or sign licensing agreement, you benefit from customer awareness of the property, which could include the perception of the quality, educational value or a certain image". Contemporary society is characterized by great quantities of not just products, but brands of uncountable numbers, not just from the domestic market, but also from the globalizing market of the world. Morgenstein (2014) stated that the world we live in is about influencers and that is all a celebrity is. The study further mentioned that celebrities are individuals who stimulate others by their activities and the virtue of their persona. They have a way of influencing the audience on what is ideal and a lot of people look up to them for inspiration. This form of advertising can be traced to the time Pope Leo XIII's 1899 endorsed the alcoholic beverage Vin Mariani, (Garthwaite, 2014). Advertisers believe that whatever these persons present 


\title{
International Journal of Business and Applied Social Science (IJBASS)
}

\author{
E-ISSN: 2469-6501 \\ VOL: 7, ISSUE: 12 \\ December/202 1 \\ DOI: http://dx.doi.org/10.33642/ijbass.v7n12p3 \\ https://creativecommons.org/licenses/by/4.0/
}

as good, will be seen as being good by the audience. As celebrities boost the image of products and services, they could be advertised on Billboards, Television, Radio, or even Newspapers and magazines. This has become a trend and can be considered as a winning formula for product marketing and brand building (Mukherjee, 2009).

Influence is the ability to have a strong effect on someone or something. Celebrities have a stronghold on many of their followers who look up to them, thereby having a stronghold on them. A lot of people especially our young ones of today, dress a certain way because their favorite celebrity dresses that way, or have a unique haircut like that of a celebrity they adore. It is said that some use any product they hear that a celebrity that they love uses.

A brand is the "name, term, design, symbol or other feature that identifies one seller's product distinct from those of other sellers" (Okoro, 2013). Brand image in its simplest form is the general impression of a product held by real or potential consumers. It contains the target market's interpretation of the product's attributes, benefits, usage situation, users, and manufacturer/marketer's characteristics. It is important when using celebrities for advertisement that they (the celebrity) should have no scandal as these scandals can affect the brand image of the product being endorsed by the celebrity. Also, a celebrity being used to advertise a particular product should not be seen using another product separate from that which he or she endorses.

Slim Tea is said to be a natural weight loss detoxification tea that flushes body fat while detoxifying the system. It aids weight loss by increasing metabolism, which accelerates fat burn and calorie expenditure. There are so many products that claim to be a weight loss solution and so many brands out there selling different types of tea to help with weight loss. Due to this, some of these products employed the services of celebrities to promote their products. Slim teas claim to help the drinker lose weight more quickly when they are consumed regularly with little or no exercise. Although there are many other slimming products and some tea products are advertised and sold as slimming teas. Some slimming teas are herbal teas that contain ingredients like dandelion or aloe, while others are based on green tea.

Slimming teas work in different ways, which include; boosting metabolism, acting as a diuretic or laxative, and suppressing appetite. Slim Tea, like so many other slimming products, employed the services of celebrities to use their popularity to strengthen their brand and sell their products by endorsing them through performances, advertisements, words, demonstrations, and other modes of communication in the mass media. There is a need to measure the level of success of this practice and the influence of celebrity endorsement on the brand image of slim tea among female undergraduates. This success is measured by ascertaining the level of acceptance and patronage of slimming tea and the level of influence celebrities exert on the buying decisions of customers.
Furthermore, there is a need to ascertain other factors that influence buyers' decisions beyond celebrity endorsement and this forms the crux of this study.

\section{Problem Statement}

In recent times, virtually everyone is exposed to the mass media and as such will most likely come across thousands of advertisements on an average per day. The thing about advertisement is that, after it has been viewed, listened to, or read about through these various mass media, the viewers tend to forget $80 \%$ of the information within 24 hours. Therefore, advertisers decide to make use of celebrities to reinforce their marketing messages to enable customers to retain the message. Sometimes when you forget an advert, the moment you recall the celebrity used for the advert, you automatically recall the advertisement. This goes further to explain why there is an increase in the amount of celebrity endorsement practices in the advertising industry today. Previous studies have shown that many celebrity endorsements fail because marketers identify celebrities they like in an emotive and un-researched manner, and then create advertisements to force-fit the celebrities into the creative concept. Hawkins, Best, and Coney (2001), insist that using a celebrity unrelated to the product shifts the attention of the customers to the celebrity, rather than the brand and this affects the intended message negatively.

Advertisers therefore should be mindful of the fact that when you use a wrong celebrity to advertise a product, it shifts the attention from the brand to the celebrity and also reduces the image of the endorser, the brand, and the firm. This study, therefore, explores the influence of celebrity endorsement on the purchase of Slim Tea by female undergraduates in selected southeast Nigerian Universities.

\section{Objectives of the study}

The study aims to explore the influence of celebrity endorsement on the brand image of slim tea among female undergraduates in selected southeast Nigerian universities. Specifically, the study aims to determine;

(i) The relationship between celebrity endorsement and purchasing habits of undergraduate students as regards slim tea.

(ii) How celebrity choice influences the purchasing tendency of slim tea products

(iii) The challenges resulting from celebrity influence on purchasing tendencies of female undergraduate students.

(iv) Measures that can be taken to ameliorate these challenges

The scope of the study covers female undergraduates of the University of Nigeria, Nsukka, Michael Okpara University of Agriculture, Umudike, Ebonyi State University Abakaliki, and Madonanna University Okija who make use of Slim Tea. The study is designed to cover both the practical and theoretical effects of celebrity endorsement among female undergraduates. The study is limited to "SLIM TEA" being one of the most popular slimming tea products in Nigeria and these particular students, which are the female undergraduates 


\title{
International Journal of Business and Applied Social Science (IJBASS)
}

\author{
E-ISSN: 2469-6501 \\ VOL: 7, ISSUE: 12 \\ December/202 1 \\ DOI: http://dx.doi.org/10.33642/ijbass.v7n12p3 \\ https://creativecommons.org/licenses/by/4.0/
}

in University of Nigeria, Nsukka, Michael Okpara University of Agriculture, Umudike, Ebonyi State University Abakaliki, and Madonanna University Okija.

This study is significant because it will help in promoting an understanding of the influence of celebrity endorsement on the purchase of slim tea among female undergraduates in selected southeast Nigerian universities. This study will be of great assistance to advertising practitioners, manufacturers, producers, distributors, and the consumers of slimming tea products as well as research students as findings will contribute to existing literature related to celebrity endorsement. It also creates a link to how the celebrities used in advertising a product affects the consumers' inclination of the students in consuming the product. It will help to show how advertisement which is a branch of mass communication affects consumption because consumption is one of the main drivers of the economy. Consumption contributes massively to the Gross Domestic Product of Nigeria. Increasing consumption leads to increased economic activity, thus the study aims at highlighting how the advertisement or advertising industry can bring about a boost in domestic consumption. Also, the study shows how media affect consumption because celebrity endorsement is aimed at portraying the product and services in good light.

\section{Theoretical framework}

The social Relations Theory and the Generalization theories were used for this study.

\section{The Social Relations Theory}

This theory was propounded in 1970 by Melvin De Fleur and some of the principles/assumptions of the theory include: (i) members of the mass media audience belonging to the same categories interact or relate with each other, and (ii) the interactions and relationships among members of the same social categories determine the effect of mass media messages on them. This theory is more like the social categories theory but its emphasis is on the relationship or interaction between members of the same social category. The theory is anchored on the findings that people's reaction to a mass media message and their action upon it is modified by their informal social relationships with friends and other social groups. This, therefore, means that there is an existence of informal social relationships among members of the audience and these relationships will modify how given individuals will react to a message that comes to their attention via the mass media. Despite being exposed to the same message, acceptance or rejection of the message is not always the same, but with the help of external forces like friends and family, one can either accept a message or refuse a message based on what the other person feels about it.

This theory makes us understand that one's friend can influence the other to either accept a given message or otherwise. It is of relevance to the study because most times when people are exposed to an advertisement, some go a step further by trying out the products being advertised after which they share their experiences with friends, family, or social groups they belong to, especially when it relates to household equipment or cosmetic, beverages, etc. For instance, an advert on slimming tea that claims to help an individual lose weight in less than a month without exercise can be believed by an audience who are fat and shapeless and desperately want to shed weight, especially if the advert is endorsed by a slim celebrity who was previously big, This makes the individuals automatically think that the celebrity used the product being advertised and as a result, he or she buys the product based on trust in the advert, whatever outcome gotten is likely to be shared with a friend or family member who has the same problem. If the advert turns out to be deceptive, then a negative reaction will occur as the consumer will discourage other people around him or her from buying the product based on personal experience.

\section{The Generalization Theory}

Generalization explains how we can learn something in one situation and apply it to other similar situations. The theory was propounded by Janis Hovland in 1967. The assumptions of the theory are as follows; (i) evidence of validity obtained in one situation can be generalized to another situation without further study of the validity of the new situation; (ii) variables can be generalized from one situation or setting to another similar set of circumstances; (iii) the extent to which predictive or concurrent evidence of validity can be used as criterion-related evidence in a new situation is, in large measure, a function of accumulated research; (iv) the theory recognizes persuasion as a process and (v) the theory is heuristic and therefore seeks to predict human reaction or behavior. The theory espouses the possibility of the transfer of values, attitudes, and thought patterns from one given role to another social role. Generalization is a mental process that, with the aid of abstraction and comparison, discovers the qualities common to a class of individual things and unites them in a single idea. The theory applies to this study which looks at consumer reactions to deceptive advertising. It can be called deceptive advertising because not everything being advertised is real. Most adverts exaggerate the efficacy of the product or service and sometimes fail to mention the side effects of using the product or service.

Methodology

The survey method was used in this research because a large amount of data can be easily collected from a variety of people and it allows researchers to examine many variables (demographic and lifestyle, information, and attitudes and to use a variety of statistics to analyze the data (Wimmer and Dominick, 2014). The survey method allows the collection of a large amount of data from a sizeable population in a highly economical way (Saunders, Lewis, and Thornhill, 2003). Also, the survey method proved to be the most convenient and costeffective design to assess the influence of celebrity endorsement on the purchase of slim tea by female 


\author{
E-ISSN: 2469-6501 \\ VOL: 7, ISSUE: 12 \\ December/2021 \\ DOI: http://dx.doi.org/10.33642/ijbass.v7n12p3 \\ (C) (†) \\ https://creativecommons.org/licenses/by/4.0/
}

undergraduate students in selected southeast Nigeria Madonna University Okija. The main focus of this study is the universities. influence of celebrity endorsement on the purchase of slim tea by female undergraduate students in selected Universities in

\section{Population of Study}

For this study, the general population consists of undergraduates in selected southeast Nigerian Universities in Nigeria. These universities are; University of Nigeria Nsukka (UNN), Michael Okpara University of Agriculture, Umudike (MOUAU), Ebonyi State University, Abakiliki (EBSU), and the southeast geopolitical zone. The choice of female university undergraduate was informed by observations that females are the largest consumers of slimming tea products and that most of the celebrity endorsers of slimming tea products are female celebrities as well.

Table 1: Total Population figure of undergraduates of the four selected universities

\begin{tabular}{lllcc}
\hline S/N & Name of the University & Total Population & Male & Female \\
\hline $\mathbf{1}$ & University of Nigeria, Nsukka & 37,922 & 17,084 & 20,838 \\
$\mathbf{2}$ & Michael Okpara University of & 27,750 & 17,970 & 19,780 \\
& Agriculture, Umudike & & & \\
$\mathbf{3}$ & Ebonyi State University & 25,391 & 12,179 & 13,212 \\
$\mathbf{4}$ & Madonna University Okija & 6,155 & 2,976 & 3,179 \\
& Total & $\mathbf{9 7 , 2 1 8}$ & $\mathbf{5 0 , 2 0 9}$ & $\mathbf{5 7 , 0 0 9}$ \\
\hline
\end{tabular}

(Source: Field data 2021)

For the purpose of this study, the population is female undergraduates of the four selected universities.

Table 2: Population figure of female undergraduates of the four selected universities

\begin{tabular}{llll}
\hline S/N & Name of the University & Figure & Percentage \\
\hline $\mathbf{1}$ & University of Nigeria, Nsukka & 20,838 & $36.5 \%$ \\
$\mathbf{2}$ & Michael Okpara University of Agriculture, & 19,780 & $35 \%$ \\
$\mathbf{3}$ & Ebonyi State University & 13,212 & $23.1 \%$ \\
$\mathbf{4}$ & Madonna University Okija & 3,179 & $5.5 \%$ \\
& Total & $\mathbf{5 7 , 0 0 9}$ & $\mathbf{1 0 0 \%}$ \\
\hline
\end{tabular}

Sample Size

The required sample used for this study was determined by using the Australian calculator as follows

Confidence Level $=95 \%$

Population size $=57,009$

Confidence interval $=0.05$

Upper limit $=0.55$

Lower limit $=0.45$

Relative Standard Error $=5.10$

Sample size $=382$

There is hardly a 100 percent response rate in survey research, therefore, the researcher did an oversample to make up for copies of the questionnaire, which may be returned or not, or would be filled wrongly. Bertlett, Kotrlik, and Higgins (2001 as cited in Ekwe, 2012) states that "if the researcher decides to use oversampling, let him estimate the response rate as a means of calculating for it" (pg.59). Therefore, the sample size for this study is 400

\section{Sampling Technique}

The study adopted the multistage sampling technique. This sampling technique divides large populations into stages to make the sampling process more practical. There were three stages implemented in this process. In stage 1 , the simple random sampling was used, this method was used to select four universities in Southeast Nigeria, namely; University of Nigeria Nsukka $(20,838)$, Micheal Okpara University of Agriculture, Umudike (19,780) Ebonyi State University $(13,212)$, and Madonna University Okija $(3,179)$. In stage 2, stratified sampling was used. This is a probability sampling technique wherein the researcher divides the entire population into different subgroups or strata, then randomly selects the final subjects proportionally from the different strata relative to the total population used in this study. The sample size of each stratum in this technique is proportionate to the population size of the stratum when viewed against the entire population. This means that each stratum has the same sampling fraction. Therefore, proportionate stratified random sampling was used 


\author{
E-ISSN: 2469-6501 \\ VOL: 7, ISSUE: 12 \\ December/2021 \\ DOI: http://dx.doi.org/10.33642/ijbass.v7n12p3 \\ (c) $\underset{B Y}{(7)}$ \\ https://creativecommons.org/licenses/by/4.0/
}

to get the number of sampled respondents from the selected schools namely; University of Nigeria Nsukka (20,838), Micheal Okpara University of Agriculture, Umudike $(19,780)$ Ebonyi State University (13,212), and Madonna University Okija $(3,179)$. Therefore 200 copies of the questionnaire were distributed to female students in the University of Nigeria, Nsukka, 100 was shared with Michael Okpara University of Agriculture, Umudike, 50 was shared to Ebonyi State University and 50 was shared to Madonna University Okija respectively. The third stage utilized purposive sampling also known as the judgmental sampling technique was used. Osuala (2005) states that, in purposive sampling, the chance of selection for each element in the population is unknown and for some elements is zero. Emaikwu (2010), "in purposive sampling purposive elements, which satisfy some predetermined criteria, are selected". Also, Ohaja (2003) states: "Purposive sampling is used when a researcher seeks certain characteristics in his sampling elements and he wants to ensure that those chosen have those characteristics. He, therefore, eliminates other members of the population and works with those that meet the requirements. Therefore, the technique is appropriate for the third and final stage as it was used to select female respondents based on their knowledge or opinion of the subject of study.

\section{The instrument for data collection}

A structured questionnaire was used for data collection for this study. The questionnaire contained 20 items. The Questionnaire contained open and close-ended questions and the copies were administered by hands by the researcher and one research assistant. The research instrument was face validated by three experts Mass Communication lecturers in the University of Nigeria Nsukka. The Cronbach Alpha Coefficient was used to ascertain the reliability of the research instrument. A reliability score of 0.86 was obtained, showing the internal consistency of the research instrument.

\section{Data Collection Procedure}

The method adopted in collecting data for this study is divided into two, which are the primary and the secondary sources of data collection to gather accurate information. The primary source of data collection was through the distribution of the questionnaire. This method enables the researcher to gather first-hand information from the respondents, while the secondary source of data collection was obtained from related literature, books, records, libraries, and journals. A total number of 400 copies of the questionnaire were distributed by hand. However, a total of 392 copies of the questionnaire were filled and returned, this represents $98 \%$ return.

\section{Method of Data Analysis}

Data collection was mainly by the use of a structured questionnaire that had closed-ended and open-ended questions. According to Ogbuoshi (2006)," data do not become meaningful or useful until they have been analyzed". For proper analysis of this study, the quantitative descriptive data analysis tool was used in analyzing the collected data. Data collected were analyzed using the analysis of the simple percentage and were presented with the help of tables and graphs. This method allows the researcher to explain the data collected and collated from the questionnaire without the use of complex mathematical models. The formula for the simple percentage is shown below:

Percentage $=\underline{\text { Actual response }} \times \underline{100}$

Total sample size 1

Where actual response $=$ number of respondents.

Total sample size $=$ total number of respondents

The data were measured in terms of the frequency and percentage distribution of the different categories of variables displayed in the table. Presenting data on tables enables one to comprehend and interpret the mass of data rapidly and to grasp significant details and relationships at a glance. (Okoro,2001) affirms that the use of graphs made a quick lasting and accurate impression of the significant facts and also made the points clearer. The criterion for the acceptance of a questionnaire item is that the weighted mean score is 2.50 and above. Any item with a score below 2.50 was rejected.

\section{Results and Findings}

This study took a total sample size of 400 , and thus 400 copies of questionnaires were distributed. However, a total of 392 copies of the questionnaire were filled and returned, indicating a 98\% return rate. The highest [proportion of respondents in this study is within the age range of 16-20 years $(39.29 \%)$, followed by respondents within the age range of 21 25 years old (29.33\%). $22.7 \%$ of the respondents are within the age range of 26-30years while $8.68 \%$ are 31 years old or older. Also, a vast majority of the respondents $(81.12 \%$ are single, while $11.99 \%$ are married, $6.12 \%$ are engaged to be married while a very low proportion of respondents $(0.77 \%)$ are divorced.

\section{Answering the Research Questions}

The findings of the study are hereby presented based on the specific objectives and research questions of the study.

\section{Research Question 1}

What is the relationship between celebrity endorsement and purchasing habits of undergraduate students as regards slim tea?

Table 3 shows the mean responses of respondents on the relationship between celebrity endorsement and purchasing habits of female undergraduate students as regards slim tea. 
Table 3 Mean responses on the relationship between celebrity endorsement and slim tea purchasing habits of female undergraduates.

\begin{tabular}{lllll}
\hline S/N & Item & X & SD & Remark \\
\hline $\mathbf{l}$ & Actresses influence your purchase habit of slim tea Musicians & 3.91 & 0.55 & Accepted \\
$\mathbf{2}$ & influence your brand perception of slim tea On Air Personalities & 3.72 & 0.59 & Accepted \\
$\mathbf{3}$ & (OAP) influence your purchasing habits of slim tea & 3.51 & 0.61 & Accepted \\
$\mathbf{4}$ & Celebrity models influence purchasing habits of slim tea & 4.01 & 0.72 & Accepted
\end{tabular}

Responses showed that movie actresses and musicians significantly influence female students' purchasing habits pertaining to slim tea. The responses further showed that on-air personalities (such as show presenters), as well as celebrity models, significantly influence the female undergraduate student's purchasing tendencies of slim tea.

\section{Research Question 2}

How does celebrity choice influence the purchasing tendency of slim tea on that part of female undergraduate students?

Table 4 below shows the mean response of respondents on how celebrity choice influences purchasing tendency of slim tea on the part of female undergraduate students.

Table 4: How celebrity choice influences purchase tendency of slim tea

\begin{tabular}{lllll}
\hline S/N & Item & X & SD & Remark \\
\hline 1. & $\begin{array}{l}\text { Celebrity popularity influence buying decision of the } \\
\text { product }\end{array}$ & 4.01 & 0.61 & Accepted \\
2. & $\begin{array}{l}\text { Perceive slim tea as potent because of celebrity } \\
\text { endorsement }\end{array}$ & 3.77 & 0.59 & Accepted \\
3. & $\begin{array}{l}\text { Recommended by friends and family because celebrities } \\
\text { use it }\end{array}$ & 3.82 & 0.72 & Accepted \\
4. & Deem slim tea a credible consumer good & 3.51 & 0.65 & Accepted \\
\hline
\end{tabular}

Response in table 4 showed celebrity popularity influences slim tea buying decisions of female undergraduate students and these students also perceive slim tea as being potent due to the fact that it is used by celebrities. Responses further showed that these students also recommended slim tea for friends and family because it is being endorsed by celebrities.

\section{Research Question 3}

Table 5: Mean response of respondents on challenges that arise from celebrity influence on slim tea purchase tendencies of female undergraduate students

\begin{tabular}{lllll}
\hline S/N & Item & $\mathrm{X}$ & $\mathrm{SD}$ & Remark \\
\hline 1. & Inaccurate customer match-up with celebrity. Decline & 3.65 & 0.61 & Accepted \\
2. & in celebrity's career performance & 3.72 & 0.65 & Accepted \\
3. & Celebrity's lifestyle not in sync with product Non-appeal & 3.51 & 0.65 & Accepted \\
4. & $\begin{array}{l}\text { of celebrity to segments of company's market } \\
\text { Inaccurate presentation of facts because a }\end{array}$ & 3.01 & 0.55 & Rejected \\
& celebrity is involved & 3.72 & 0.68 & Accepted \\
\hline
\end{tabular}

Responses in table 3 showed that inaccurate customer celebrity's career performance are significant challenges that match-up with celebrity endorsers as well as decline in the occur in their influence of slim tea purchasing tendencies of influence on slim tea purchase tendencies of female undergraduate students?

Table 5 shows the mean response of respondents to research question 3 on the challenges that arise as a result of celebrity influence on the slim tea purchase tendencies of female undergraduate students. 


\author{
E-ISSN: 2469-6501 \\ VOL: 7, ISSUE: 12 \\ December/2021 \\ DOI: http://dx.doi.org/10.33642/ijbass.v7n12p3 \\ https://creativecommons.org/licenses/by/4.0/
}

female students. This can be attributed to the fact that these students intensely monitor the career performances of these celebrities to make their decisions. Responses also show that inaccurate presentation of facts about the product is a significant challenge that arises because of celebrity influence of slim tea purchase tendencies of female students. However, non-appeal of celebrity used for adverts to the market segment served by the slim tea product did not exert a significant adverse effect on the slim tea purchase tendencies of female undergraduate students.

Research Question 4: What measures can be used to ameliorate these challenges?

Table 6 below shows measures that can be taken to ameliorate the challenges that arise as a result of celebrity endorsement of slim tea.

Table 6: Mean response of respondents on measures to ameliorate how celebrity choice influence product brand image

\begin{tabular}{lllll}
\hline $\mathrm{S} / \mathrm{N}$ & Item & $\mathrm{X}$ & $\mathrm{SD}$ & Remark \\
\hline l. & Careful selection of product endorsers & 4.25 & 0.65 & Accepted \\
2. & Careful content presentation during adverts & 3.71 & 0.61 & Accepted \\
3. & $\begin{array}{l}\text { Branding contracts should include performance } \\
\text { benchmarks for the celebrity }\end{array}$ & 3.92 & 0.72 & Accepted \\
4. $\quad \begin{array}{l}\text { Endorsers lifestyle and personality should } \\
\text { identify with the product }\end{array}$ & & & \\
\hline
\end{tabular}

Response in table 6 showed that careful selection of product endorses, as well as careful presentation of content during adverts, are significant measures that can be employed towards ameliorating the challenges that occur due to celebrity endorsement. Furthermore, performance benchmarks for celebrity brand ambassadors as well as ensuring that only endorsers who are lifestyle are in sync with the product they are endorsing.

\section{Discussion of Findings}

Findings from this study showed that actresses, musicians, and on-air personalities (OAPs) significantly influence the slim tea purchase habits of female undergraduate students. These findings are in tandem with the study of Chan (2013) who mentioned that using a celebrity in an advertisement would increase brand awareness, attract the celebrity's fans, encourage trial, and enhance purchase confidence. Also, Ghaffarietal (2016), in his study discovered that corporate image has a significant relationship with celebrity endorsement. This reaffirms that advertising appeal significantly and partially mediates the relationship between celebrity endorsement and consumer purchase intentions, and that, advertising appeals positively to the relationship between celebrity endorsement and consumer purchases intention. Furthermore, the findings in this research question also show that On-Air-Personalities significantly influence the perception of female students to slim tea products. This finding aligns with the postulations of Coulter, Zaltman, and Coulter (2001), which were of the view that personalities that are seen on-air, especially on television, significantly influence the individual perception of products and services. This they attributed to the fact that their fans are continually exposed to them and think that using products and/or services that they endorse is a way of accentuating the fact that they are fans of the celebrity and also that the fact that a celebrity is endorsing the product makes it a credible one.
The findings from the second research question showed that celebrities influence the choice of slim tea consumption of female undergraduate students by their popularity and these students perceive the slim tea product as being potent because it is used by celebrities. Findings further showed that slim tea products are recommended by family and friends because it is used by celebrities and it is deemed credible because celebrities make use of it. These are in tandem with the postulations of Reid and King (2003) who mentioned that wield enormous influence on their fans and this could lead to them patronizing products endorsed by these celebrities even without enquiring about possible side effects product. The findings are also in agreement with the study of Ifeanyichukwu (2012), who finds that the use of celebrities can influence young adults in their purchase decisions and that celebrity will go a long way in positioning a brand in the minds of the consumers and that it is important for firms to associate with celebrities with the high level of attractiveness and popularity, this goes a long way in getting the interest of young adults and that any dent on the image of the celebrity affects the brand as well. In addition, Nor- Pujawati, Said, Norani, and Napu (2015) opined that brands that identify with popular celebrities are felt to be credible and effective by audiences. The study further mentioned that such brands usually witness increased patronage as they are effectively marketed by these celebrities, not only during events but also in their normal daily lives. Patronizing these products give audiences the feel of using the same products that their favorite celebrities use. The findings in research question 2 also show that undergraduate students recommend slim tea products for family and friends due to celebrity endorsement. This is in agreement with the postulations of Tantiseneepong, Gorton, and White (2012) who mentioned that individuals most times market products not just based on their effectiveness and credibility but also based on the celebrity who is endorsing the product. The study further opined that the effectiveness of a 


\title{
International Journal of Business and Applied Social Science (IJBASS)
}

\author{
E-ISSN: 2469-6501 \\ VOL: 7, ISSUE: 12 \\ December/202 1 \\ DOI: http://dx.doi.org/10.33642/ijbass.v7n12p3 \\ https://creativecommons.org/licenses/by/4.0/
}

product is usually measured by the celebrity endorsing it, thus the tendency for recommendations to be made to family and friends based on the celebrity endorsing the product. In another study, Shamaila, Ayuba, Qasim, Shafique, and Ali (2016) also mentioned that celebrity endorsement significantly influences consumer intentions and purchase of products and services. They further mentioned that the brand image of a product is significantly influenced both the corporate image of the organization and also the caliber of customers that it wishes to attract.

The findings from the third research question showed that the challenges that affect celebrity endorsement of slim tea are inaccurate consumer matchup with the celebrity endorser and decline in career performance of the celebrity. Findings further shower showed celebrities not being in sync with the market segment being served, as well as inaccurate presentation of product facts are significant challenges militating against celebrity endorsement influence on the purchasing habits of slim tea. These are in tandem with the findings of Shamaila, Ayubia, Qasim, Shafique, and Ali (2016) who opined that celerity endorsement of certain products and services give the followers of those celebrities the impression that the product is effective and credible. In addition, they opined that the celebrity endorsing a product probably uses the product, thus confirming the credibility and effectiveness of the product.

The findings from research question four show that careful selection of celebrity endorsers and careful content selection are significant measures that can be used to ameliorate the challenges that occur as a result of celebrity influence on slim tea product purchase habits. Furthermore, respondents agreed that branding contracts should include performance benchmarks for the celebrities, as well as a careful selection of celebrities whose lifestyles are in tandem with the products they are endorsing. These findings are in tandem with McCracken (1989) who mentioned that celebrity endorsement of products has a psychological effect on the fans of the celebrities as they make use of such a product in a bid to identify with both the celebrity and the product. The study further mentioned that many consumers consider celebrities as role models and in a bid to emulate their role models, tend to consume the same products and services that their role models endorse.

\section{Conclusion}

Advertising is a marketing communication. It is an audio or visual form of marketing communication that employs an openly sponsored, non-personal message to promote or sell a product or service. Due to the competiveness of products and services, business organizations make use of advertisement to create awareness, educate and inform the public of its goods and services as well as to remind existing customers that the product and services still exist. Now the use of celebrities as a marketing strategy is a way of going the extra mile to capture the audience as so many research works believe that people tend to go for certain products and services because someone they admire says it is good and ideal. Slim tea as well as many other slimming tea products are aware of the competition. Knowing well that they are not the only company that offers slimming solutions; therefore, they made use of celebrity advertisements as strategies to lure the female populace to purchase these products. Based on the findings, the following conclusions were drawn; the purchasing habits of the population towards "Slim Tea" advertisements were influenced to purchase the products. The students' propensities to purchase these products were significantly influenced by the celebrities who were used to endorse the product. Furthermore, these students based their purchase decisions purely on their followership of the celebrity or celebrities endorsing the slim tea product and not on any accurate information about the product itself. The study further showed that these celebrities are the role model of the students, thus informing the sort of significant influence they wield on the students. Also, the student judge product credibility based on the celebrity endorsing the product and not based on the internal components of the product. Thus seeing a slim female celerity makes the students believe that their slim body frame was attained by consuming slim tea without ascertaining if such an individual did something else to attain the body shape. Findings from the work also show that the ability of the students to identify with the celebrity endorsing the product also influenced their consumption of slim tea. Thus, for example, a female student of Theatre and Film Studies in the University will likely consume a product that is endorsed by a female actress. In addition, social media plays a significant role in influencing the product consumption choices of female students. It was seen that female undergraduate students' choice of slim tea products also was influenced by advertisements done on social media platforms like Facebook, Instagram, and Twitter. Furthermore, the uniqueness of product adverts on social media also influences students' propensity to consume these slim tea products. This is attributed to the fact that these students spend a large proportion of their time browsing through the different social media platforms, thus they are successfully swayed by the advertisements they see on these social media platforms. Thus it makes it imperative that social media platforms be effectively used by business organizations in effectively marketing their products and services. This also makes it imperative that regulatory bodies utilize social media platforms in educating consumers about the possible hazards as well as benefits of consuming slim tea products.

\section{Recommendations}

Based on the findings of this study, the under listed recommendations are hereby made for consideration:

- Advertisers should make use of the right celebrities to promote the brand image of their products. Using the right celebrity to promote the brand image of a product matters a lot because you have to get a celebrity that is 


\author{
E-ISSN: 2469-6501 \\ VOL: 7, ISSUE: 12 \\ December/2021 \\ DOI: http://dx.doi.org/10.33642/ijbass.v7n12p3 \\ (c) $\underset{B Y}{(i)}$ \\ https://creativecommons.org/licenses/by/4.0/
}

in sync with the products and services being advertised to enable a big marketing splash.

- The side effects of these slim tea products should also be mentioned by celebrities to effectively educate consumers on the slim tea products they consume. A lot of companies will not agree with this because they feel it will discourage consumers from purchasing the product. There is hardly any product and services that do not have advantages and disadvantages hence, the celebrity endorser must highlight the effects of these slim tea products as these will help enhance better ways to consume them to avoid some dangers. Advertisers focus on the speed of the weight loss, with immediate weight loss being observed in some cases. However, most weight loss that people experience is caused by either loss of water or loss of solid waste. Also, there is little evidence showing that slimming tea helps with weight loss as The United States Food and Drug Administration (FDA) does not recognize any slimming tea as being effective. If celebrity endorsers claim that these slim tea works for them, then they should properly educate their consumers to inform a better consumption to get results.

- Business organizations should consider celebrities whose profession and lifestyle are in sync with the products and services that they are to endorse. Celebrities are brands on their own and people idolize celebrities, so when famous people are seen in advertisements promoting a new product, audiences are prompted to buy that product, either subliminally or directly. It is important to note that using a celebrity to endorse a product does not guarantee $100 \%$ success of that product; other factors need to be put in place such as price, etc. If the celebrity used to promote a product has enough brand power of their own, they don't even need to explicitly endorse a product to see the effects of their influence on sales or to be used in promotional materials. If an advertising industry wants a celebrity to endorse Slim tea, for example, they should make use of a fitness celebrity as this will show that slim tea enhances fitness goals.

- Slim tea consumers should strive to be better informed about the product they are consuming. This they can achieve by carefully studying to ascertain the chemical components of the products to be sure that they are not consuming poisonous substances. A lot of slimming tea products cause dehydration, cramping, nausea, aggravate constipation, dependency, weakened colon, and reduced potassium levels, which is dangerous for people with heart problems. Most ingredients are benign, some may cause severe side effects in certain people, some slimming teas may contain laxatives and diuretics, which may cause health complications, thus it is important for consumers to be better informed of the contents of the products before purchase and consumption.

- Media platforms should be used not only by producers to market their products and services to their target markets but also by regulatory agencies for promoting consumer information to promote responsibly and informed consumption. The federal government of Nigeria had set up agencies such as the National Agency for Food and Drug Administration and Control (NAFDAC), the Standards Organization of Nigeria (SON), the National Drug Law Enforcement Agency (NDLEA) to regulate and promote responsible and informed consumptions. These agencies should make use of media platforms to sensitize consumers of the advantages and disadvantages of consuming certain products as well as educate consumers on how to know if a product is good for consumption or not.

- Innovative forms of advertising and product packaging should be adopted by producers of slim tea products to attract increased patronage of the student target market. Celebrity endorsement is not enough to improve sales, another factor that should be put into consideration is the packaging. Product packaging influences consumer buying behavior and also serves as a good marketing strategy.

\title{
References
}

Chan, K. Yu-Leung N. and Edwin K. (2013)."Impact of Celebrity Endorsement in Advertising on Brand Image Among Chinese Adolescents." Young Consumers, 14 (2): 167-179.

Coulter, R., Zaltman, G., and Coulter, K. (2001). Interpreting Consumer Perceptions of Advertising: An Application of the Zaltman Metaphor Elicitation Technique. Journal of Advertising, 30(4): 1-21.

Emaikwu, S. (2010). Fundamentals of Research Methods and Statistics. Makurdi: Selfers Academic Press Limited.

Friedman, H. and Friedman, L. (1979). Endorser Effectiveness by Product Type. Journal Advertising Research, 19(5): 67-71.

Garthwaite, C. L. (2014). Demand Spillovers, Combative Advertising, and Celebrity Endorsements. American 
Economic Journal: Applied Economics, 6 (2): 76-104. http://dx.doi.org/10.1257/app.6.2.76.

Hawkins, B. and Coney, L. (2001). Consumer Behavior, Building Marketing Strategy. New York: McGraw-Hill Higher Education.

Ifeanyichukwu, C. (2012). Effect of Celebrity Endorsements on Consumers Purchase Decision in Nigeria. International Research Journal of Management, IT \& Social Sciences (IRJMIS) Vol. 3 Issue 9.

McCracken, G (1989). Who is the Celebrity Endorser? Cultural Foundations of the Endorsement Process. Journal of Consumer Research, 16(3): 310-321.

Morgenstein, T. (2014). The Value of Celebrity Endorsement by Rob Boffard Business Reporter, published 11 thDecember 2014

Mukherjee, D. (2009). Impact of Celebrity Endorsements on Brand Image. Retrieved May 2014 from http://ssrn.com/abstract=1444814.

Nor Pujawati, B.; Said, W.; Noraini, B.; and Napu, B. (2015) "Celebrity and Non-Celebrity Endorsement Effectiveness On Consumers' Attitude Towards Advertisement", International Academic Research Journal of Business and Technology 1(2) 2015, Page 51-57.

Ohaja, E. (2003). Mass Communication Research and Project Report Writing. Lagos: John 108 Letterman Ltd. Okoro, N. (2001). Mass Communication Research: Issues and Methodologies. Nsukka: AP Express.

Okoro, N. (2013). The business of advertising (2nd ed). Lagos: St Beneditte Ogbuoshi, L. (2006). Understanding Research Methods and Thesis Writing. Enugu, Linco Publishers. Osuala, E. (2005). Introduction of Research Methodology. Onitsha, Africana-FEP Publishers Limited.

Reid, L. and King, K. (2003). Agency creative like TV advertising best. Newspaper Research Journal, 24 (3): 6-22. Schiffman, L. and Kanuk, L. (2000). Consumer Behaviour (7th ed.). New York: Prentice Hall

Shamaila G., Ayubia R., Qasim A., Shafique U. and Ali A. (2016). Does Celebrity Endorsement Influence the Consumer Purchase Intentions \& Corporate Image? Mediating Role of Advertising Appeal.

Saunders, M., Lewis P. \& Thornhill, A. (2003). Research Methods for Business Students. 3rd Edition. England: Prentice - Hall.

Silvera, D. and Austad, B. (2004). Factors Predicting the Effectiveness of Celebrity Endorsement Advertisements. European Journal of Marketing, 38(11/12): 1509-1526.

Tantiseneepong, N., Gorton, M. and White J. (2012), Evaluating Responses to Celebrity Endorsements Using Projective Techniques: Qualitative Market Research. An International Journal, 15 (1), 57-69.

Wimmer, R. and Dominick, J. (2014). Mass Media Research. An Introduction. 10th Edition, Wadsworth, Cengage Learning, Boston. 